Syntax Fusion : Jurnal Nasional Indonesia

P-ISSN: $x x x x-x x x x$

e-ISSN : $x x x x-x x x x$

Vol. 1, No. 1, Oktober 2020

\title{
EFEKTIVITAS PEMBELAJARAN PRAKTEK PADA PENCAPAIAN KOMPETENSI PENGETAHUAN PEMBUATAN KAIN TENUN SISWA KELAS $X$ DI SMK NEGERI 1 GUNUNG JATI CIREBON
}

\section{Yana}

\section{SMK Negeri 1 Gunung Jati}

\section{E-mail: mpd.yana@gmail.com}

\section{Abstrak}

Tujuan penelitian ini ialah untuk mengetahui: (1) Kompetensi siswa dalam menjelaskan dan membedakan proses menenun sebelum penerapan praktek, (2) Kompetensi siswa dalam menjelaskan dan membedakan proses menenun setelah penerapan praktek, (3) Efektivitas penggunaan praktek pembelajaran pembuatan kain tenun untuk pencapaian kompetensi mengetahui dan membedakan proses menenun. Pendekatan yang digunakan dalam penelitian ini ialah kuasi eksperimen, dengan desain pretest-posttest nonequivalent groups. Populasi penelitian ialah seluruh peserta didik kelas X KKBT SMK Negeri 1 Gunung Jati Cirebon yang berjumlah 108 siswa, dengan sampel X KKBT 3 sebagai kelas eksperimen dan X KKBT 2 sebagai kelas kontrol. Pengambilan sampel tersebut menggunakan teknik probability sampling atau random sampling. Pengambilan data dilakukan pada Oktober 2015. Instrumen yang digunakan adalah soal pretest dan posttest. Teknik analisis data dilakukan dengan analisis deskriptif, serta pengujian hipotesis menggunakan uji-t.Hasil penelitian menunjukkan bahwa: (1) Kompetensi siswa dalam menjelaskan dan membedakan proses menenun sebelum penerapan praktek sangat rendah, yaitu dengan ratarata 38,41 pada kelas kontrol dan 36,85 pada kelas eksperimen, (2) Kompetensi siswa pada kelas eksperimen dalam menjelaskan dan membedakan proses menenun setelah penerapan praktek lebih tinggi dari pada sebelum penerapan praktek yaitu dengan rata-rata sebesar 80,18, (3) Penggunaan praktek pembelajaran pengetahuan pembuatan kain tenun dinyatakan efektif, melihat perbedaan hasil pretest dan posttest siswa, serta perbandingannya dengan kelas yang tidak menerapkan praktek (kelas kontrol). Rata-rata hasil belajar kelas eksperimen lebih besar dari pada kelas kontrol $(80,18>72,41)$, dan thitung lebih besar dari t tabel (2,324 > 2,036) serta nilai signifikansi lebih kecil dari 0,05 ( $p<0,05$, dengan $p=0,000)$.

Kata kunci: Efektivitas praktek, Kompetensi pembuatan kain tenun, Kompetensi Pengetahuan 


\section{Pendahuluan}

Kurikulum 2013 Revisi merupakan kurikulum baru, ditetapkan untuk menggantikan kurikulum Tingkat satuan pendidikan atau KTSP yang sudah berjalan sejak tahun 2006. Kurikulum 2013 Revisi sendiri mulai diterapkan pada 2014 dengan masa percobaan selama tahun 2013. Sekolah yang menerapkan kurikulum 2013 ialah yang berjenjang SD, SMP, dan SMA/SMK. Sesuai tujuan Kurikulum 2013 Revisi yang lebih mengembangkan nalar siswa, banyak materi yang disesuaikan dan materi baru bermunculan. Pada jenjang SMK dengan jurusan KKBT Butik misalnya, materi baru yang dihadirkan dalam kurikulum ini salah satunya yaitu pengetahuan pembuatan kain tenun, yang masuk dalam mata pelajaran tekstil. Pada materi ini siswa diajarkan untuk mulai mengenal proses pembuatan kain tenun tradisional. Namun, dalam praktik pembelajarannya masih banyak mengalami kendala, seperti yang dialami SMK Negeri 1 Gunung Jati Cirebon.

SMK Negeri 1 Gunung Jati Cirebon merupakan salah satu sekolah dengan jurusan KKBT Butik yang menerapkan Kurikulum 2013 Revisi. Sesuai silabus mata pelajaran tekstil, pembuatan kain tenun masuk dalam kompetensi dasar yaitu siswa diminta dapat menjelaskan dan membedakan proses menenun. Materi ini diberikan pada siswa kelas $\mathrm{X}$ semester ganjil. Namun, kompetensi siswa dalam pengetahuan pembuatan kain tenun sangat rendah. Hal ini dibuktikan dengan hasil observasi menggunakan instrument tes berisi pertanyaan tentang materi pembuatan kain tenun, yang menunjukkan hasil $21,8 \%$ siswa mendapatkan skor di atas 70 , sedangkan $78 \%$ Siswa mendapatkan skor di bawah 70 .

Selain dengan metode penyebaran tes, observasi juga dilakukan dengan cara wawancara langsung dengan guru mata pelajaran Tekstil SMK Negeri 3 Yogyakarta. Hasilnya, guru menyatakan bahwa umumnya pembelajaran tekstil, terutama dalam materi pengetahuan pembuatan kain tenun cenderung lebih sulit, karena beberapa faktor, diantaranya yaitu model ceramah yang mampu diberikan untuk siswa, dan kebanyakan siswa menganggap materi tersebut sulit. Adapun Metode pembelajaran yang digunakan untuk menunjang proses belajar mengajar ialah video terkait materi, dan pengadaan kunjungan industri ke tempat penenunan. Sedangkan sekolah SMK N 1 Gunung Jati Cirebon dalam hal ini belum mampu memenuhi kebutuhan Metode belajar tersebut.

Walaupun terbilang cukup membantu, turun langsung ke industri dan mengamati melalui video singkat tidak lantas membuat siswa langsung mengingat semua proses dan komponen-komponen peralatannya. Permasalahan lain yang muncul, yaitu tidak seluruh proses penenunan dapat diamati siswa, karena harus menyesuaikan dengan jumlah siswa dan aktivitas industri. Maka, perlu adanya Metode pembelajaran yang bisa dibawa dan dipelajari siswa diluar jam palajaran.

Penerapan Metode tambahan seperti praktek pembelajaran dapat menjadi solusi permasalahan ini. Siswa dapat mempelajari materi menenun secara mandiri mengingat praktek dirancang sebagai program pembelajaran yang utuh dan sistematis. Praktek mengandung tujuan, bahan dan kegiatan belajar, serta evaluasi., Cakupan bahasan materi dalam praktek lebih fokus dan terukur, serta lebih mementingkan aktivitas belajar pembacanya, semua sajiannya disampaikan melalui bahasa yang komunikatif (Munadi, 2013)

Siswa akan lebih mudah mengingat materi, serta kompetensi yang mencakup prestasi belajar dan nilai kriteria kompetensi minimum dapat tercapai. Oleh karena itu dilakukanlah penelitian untuk mengukur efektivitas praktek 
pembelajaran pada pencapaian kompetensi pembuatan kain tenun siswa kelas $\mathrm{X}$ di SMK Negeri 1 Gunung Jati Cirebon, dengan membandingkan antara kelas eksperimen dengan kelas kontrol.

\section{Metode Penelitian}

Penelitian ini merupakan penelitian tindakan kelas (classroom actionresearch). Prosedur penelitian tindakan kelas yang digunakan mengikuti model (Kemmis \& Taggart, 2002). Metode pengumpulan data merupakan cara kerja untuk mendapatkan data dari obyek tertentu. Data yang didapatkan dalam penelitian dapat berupa data yang sifatnya kualitatif dan kuantitatif. Data adalah hasil pencatatan peneliti baik yang berupa fakta maupun angka (Suharsimi, 2006)

\section{Hasil dan Pembahasan}

\section{A. Hasil}

\section{Tinjauan Tentang Ranah Psikomotor Siswa Pada Mata Pelajaran Tenun}

\section{a. Ranah Psikomotor Siswa}

1) Pengertian Ranah Psikomotor

Sebagai kegiatan yang berupaya untuk mengetahui tingkat keberhasilan siswa dalam mencapai tujuan yang ditetapkan maka evaluasi hasil belajar memiliki sasaran berupa ranah-ranah yang terkandung dalam tujuan yang diklasifikasikan menjadi tiga ranah kognitif, ranah efektif, dan ranah psikomotorik . ketiga ranah ini tidak dapat dipisahkan satu sama lain secara eksplisit.

Dalam psikologi, kata motor di gunakan sebagai istilah yang menunjukan otot-otot, gerakan-gerakannya. motor juga dapat di pahami sebagai segala keadaan yang meningkatkan atau menghasilkan rangsangan terhadap kegiatan organ-organ fisik. Ranah psikomotor adalah ranah yang berhubungan dengan aktivitas fisik, misalnya lari, melompat, melukis, menari, memukul, dan sebagainya. Ranah psikomotor merupakan suatu ranah yang berkaitan dengan keterampilan atau kemampuan bertindak setelah seseorang menerima pengalaman belajar tertentu. (Simpson 1956) yang menyatakan bahwa hasil belajar ranah psikomotor ini tampak pada bentuk keterampilan (skill) dan kemampun bertindak individu.

Hasil belajar kognitif dan hasil belajar afektif akan menjadi hasil belajar psikomotor apabila peserta didik telah menunjukkan perilaku atau perbuatan tertentu sesuai dengan makna yang terkandung dalam ranah kognitif dan ranah afektif dengan materi kedisplinan menurut agama islam, maka wujud nyata dari hasil psikomotor yang merupakan kelanjutan dari hasil belajar kognitif afektif itu adalah peserta didik dapat memberikan contoh-contoh kedisiplinan di sekolah, seperti datang ke sekolah sebelum pelajaran di mulai, tertib dalam mengenakan seragam sekolah.

Keterampilan psikomotor adalah keterampilan yang merupakan integrasi fungsi motorik. Ciri keterampilan motorik adalah siswa harus melakukan sesuatu dengan menggunakan ototnya dengan atau tanpa peralatan untuk mencapai hasil yang telah di tentukan. Menurut (Gredler 1991) ciri utama motorik adalah keterampilan yang bisa bertambah sempurna melalui praktik atau latihan, yang di lakukan dengan 
pengulangan-pengulangan gerakan dasar disertai balikan dari lingkungan. Menurut (Bloom 1979) berpendapat bahwa ranah psikomotor berhubungan dengan hasil belajar yang tercapainya melalui keterampilan manipulasi yang berkitan dengan otot dan kekuatan fisik.

Menurut (Mardapi 2003), keterampilan psikomotor ada enam tahap, yaitu:

a) Gerakan refleks adalah respons motorik atau gerak tahap sadar yang muncul ketika bayi lahir.

b) Gerakan dasar (Basic fundamental movements) adalah gerakan muncul tanpa latihan tapi dapat diperhalus melalui praktik. Contoh : bergoyang.

c) Kemampuan perceptual (Perceptual obilities) adalah kombinasi kemampuan kognitif dan motorik atau gerak. Contoh : menangkap bola.

d) Kemampuan fisik (Psycal abilities) adalah berkembang melalui kematangan dan belajar. Contoh: terampil menjahit, menyanyi.

e) Gerakan terampil (Skilled movements) adalah gerakan yang tangkas dan cekatan melakukan gerakan yang sulit dan rumit. Contoh: menari dengan berdansa.

f) Gerakan indah dan kreatif (Nondiskursive communication) adalah kemampuan komunikasi dengan gerakan.

Jadi, pembentukan keterampilan motorik lebih tepat hanya dilakukan melalui kegiatan praktik. Melalui praktik yang berulang-ulang akan terbentuk kebiasaan-kebiasaan gerakan sekaligus akan menghasilkan keterampilan kerja yang lebih baik. Secara umum Ranah Psikomotor menjadi lima peringkat, yaitu mulai peringkat yang paling sederhana sampai peringkat yang paling kompleks. Adapun peringkat tersebut adalah

1) Peniruan.

2) Pemanipulasian.

3) Ketelitian.

4) Penggabungan.

5) otomatisasi.

2) Klasifikasi Ranah Psikomotor Menurut (Dave 1970) dan Simpson Dave membagi ranah psikomotor dalam lima katagori yaitu sebagai berikut:

a) Peniruan

Terjadi ketika siswa mengamati suatu gerakan. Mulai memberi respon serupa dengan yang diamati. Mengurangi koordinasi dan kontrol otot-otot syaraf. Peniruan ini umumnya dalam bentuk global dan tidak sempurna. Contoh: seorang anak didik dapat memukul bola dengan tepat karena pernah melihat hal yang sebelumnya. 
b) Manipulasi

Menekankan pada perkembangan kemampuan mengikuti pengarahan, penampilan gerakan-gerakan pilihan, dan menetapkan suatu penampilan melalui latihan. Pada tingkat isi siswa menampilkan sesuatu menurut petunjuk-petunjuk, tidak hanya meniru tingkah laku. Contoh: seorang anak didik dapat memukul bola dengan tepat karena berdasarkan petunjuk guru atau teori yang di bacanya.

c) Ketetapan

Memerlukan kecermatan, proporsi, dan kepastian yang lebih tinggi dalam penampilan. Respon-respon lebih terkorelasi dan kesalahankesalahan di batasi sampai pada tingkat minimum. Contoh: peserta didik dapat mengarahkan bola yang dipukulnya sesuai dengan target.

d) Artikulasi

Menekankan pada koordinasi suatu rangkaian gerakan dengan membuat urutan tepat dan mencapai yang diharapkan atau konsistensi internal antara gerakan-gerakan. Contoh: peserta didik dapat mengejar bola kemudian dapat memukulnya dengan cermat sehingga arah bola sesuai dengan target yang di inginkan.

e) Pengalaman

Menurut tingkah laku yang ditampilkan paling sedikit mengeluarkan energi fisik maupun psikis. Gerakannya di lakukan secara rutin. Contoh: tanpa berfikir panjang peserta didik dapat mengajar bola kemudian memukul dengan cermat sehingga arah bola sesuai dengan target yang di inginkan. Adapun ranah psikomotor menurut klasifikasi Simpson diantaranya:

\begin{tabular}{|c|c|c|}
\hline Katagori Jenis & $\begin{array}{l}\text { Kemampuan } \\
\text { Internal }\end{array}$ & $\begin{array}{c}\text { Kata Kerja Operasional } \\
\text { Perilaku }\end{array}$ \\
\hline 1) Persepsi & \begin{tabular}{|lr} 
Menafsirkan & rangsangan \\
peka & terhadap \\
ransangan & \\
diskriminasikan &
\end{tabular} & $\begin{array}{l}\text { Memilih, Membedakan, } \\
\text { Mempersiapkan, Menunjukan, } \\
\text { Mengidentisifikasi, } \\
\text { Menghubungkan. }\end{array}$ \\
\hline 2) Kesiapan & $\begin{array}{l}\text { Berkosentrasi, } \\
\text { menyiapkan diri (fisik } \\
\text { dan mental) }\end{array}$ & $\begin{array}{lr}\text { Memulai, } & \text { Mengawali, } \\
\text { Bereaksi, } & \text { Mempersiapkan, } \\
\text { Memprakasai, } & \text { Menanggapi, } \\
\text { Mempertunjukan. }\end{array}$ \\
\hline $\begin{array}{l}\text { 3) Gerakan } \\
\text { terbimbing }\end{array}$ & $\begin{array}{l}\text { Meniru contoh, } \\
\text { memainkan }\end{array}$ & $\begin{array}{l}\text { Mempraktekkan, Mengikuti, } \\
\text { Mengerjakan, Membuat, } \\
\text { Mencoba, Memperlihatkan, }\end{array}$ \\
\hline
\end{tabular}




\begin{tabular}{|c|c|c|}
\hline & & Memasang. \\
\hline $\begin{array}{l}\text { 4) Gerakan } \\
\text { terbiasa }\end{array}$ & $\begin{array}{l}\text { Berketerampilan, } \\
\text { Berpegang pada pola }\end{array}$ & $\begin{array}{l}\text { Mengoperasikan, } \\
\text { Membangun, Mengerjakan, } \\
\text { Mendemonstrasikan, } \\
\text { Memainkan. }\end{array}$ \\
\hline $\begin{array}{l}\text { 5) Gerakan } \\
\text { kompleks }\end{array}$ & $\begin{array}{l}\text { Berketerampilan } \\
\text { secara misalnya: } \\
\text { Lancar, } \quad \text { Luwes, } \\
\text { Lincah }\end{array}$ & $\begin{array}{l}\text { Mengerjakan, } \\
\text { Mendemonstrasikan, } \\
\text { Membangun, Memainkan. }\end{array}$ \\
\hline 6) Penyesuaian & Menyesuaikan diri & Mengubah \\
\hline 7) Pola gerakan & Bervariasi & Mengadaptasikan, Mengatur \\
\hline & & kembali, Membuat variasi. \\
\hline 8) Kreativitas & $\begin{array}{l}\text { Menciptakan yang } \\
\text { baru, Berinisiatif }\end{array}$ & $\begin{array}{l}\text { Merancang, Menyunsun, } \\
\text { Menciptakan, Mendesain, } \\
\text { Mengkombinasikan, } \\
\text { Mengatur, Merencanakan. }\end{array}$ \\
\hline
\end{tabular}

3) Mengembangkan Kecakapan Psikomotor

Keberhasilan pengembangan ranah kognitif juga akan berdampak positif terhadap perkembangan ranah psikomotor. Kecakapan psikomotor ialah segala amal jasmaniah yang konkret dan mudah di amati baik kuantitasnya maupun kualitasnya, karena sifatnya yang terbuka. Namun, disamping kecakapan psikomotor itu tidak terlepas dari kecakapan kognitif ia juga banyak terikat oleh kecakapan afektif. Jadi, kecakapan psikomotor siswa merupakan manifestasi wawasan pengetahuan dan kesadaran serta sikap mentalnya.

Banyak contoh yang membuktikan bahwa kecakapan kognitif itu berpengaruh besar terhadap berkembangan kecakapan psikomotor. Para siswa yang berprestasi baik dalam bidang pelajaran agama misalnya sudah tentu akan lebih rajin beribadah salat, puasa, dan mengaji.

4) Pembelajaran Psikomotor

(Leighbody 1968) menjelaskan bahwa keterampilan yang dilatih melalui praktik secara berulang-ulang akan menjadi kebisaan atau otomatis dilakukan. Sementara itu (Goetz 1981) bahwa latihan yang di lakukan secara berulang-ulang akan memberikan pengaruh yang sangat besar pada pemahiran keterampilan.

Dalam melatih kemampuan psikomotor ada beberapa langkah yang harus dilakukan agar pembelajaran mampu membuahkan hasil yang optimal. (Mills 1977) menjelaskan bahwa langkah-langkah dalam mengajar praktek diantaranya: 
a) Menentukan tujuan dalam bentuk perbuatan

b) Menganalisis keterampilan secara terperinci

c) Mendemonstrasikan keterampilan disertai dengan penjelasan singkat

d) Memberikan kesempatan kepada peserta didik untuk mencoba melakukan praktik dengan pengawasan dan bimbingan

e) Memberikan pernilaian terhadap usaha peserta didik

5) Penilaian Hasil Belajar Psikomotor

(Ryan 1980) menjelaskan bahwa hasil belajar keterampilan dapat di ukur melalui:

a) Pengamatan langsung dan penilaian tingkah laku peserta didik selama proses pembelajaran praktik berlangsung,

b) Sesudah mengikuti pembelajaran, yaitu dengan jalan memberikan tes kepada peserta didik untuk mengukur pengetahuan, keterampilan, dan sikap,

c) Beberapa waktu sesudah pembelajaran selesai dan kelak dalam lingkungan kerjanya.

(Leighbody 1968) menjelaskan bahwa hal-hal yang di nilai dalam ranah psikomontor mencakup:

a) Kemampuan menggunakan alat atau kemampuan membaca.

b) Kemampuan menyunsun urut-urutan atau tahap-tahapan pekerjaan atau mengurutkan urutan gerakan.

c) Kecepatan mengerjakan tugas.

d) Kemampuan membaca gambar atau simbol-simbol.

e) Keserasian bentuk atau ukuran yang telah di tentukan.

Penilaian dapat di lakukan pada saat proses berlangsung yaitu pada waktu peserta didik melakukan praktik. Penilaian psikomotor dapat di lakukan dengan menggunakan observasi atau pengamatan yaitu dengan mengukur tingkah laku individu misalnya tingkah laku peserta didik ketika praktik, partisipasi peserta didik dalam simulasi.

Pengukuran ranah psikomotorik di lakukan terhadap hasil belajar yang berupa penampilan. Hal-hal yang di ukur meliputi:

a) Gerak reflek.

b) Gerak dasar.

c) Kemampuan perceptual.

d) Gerakan fisik.

e) Gerakan terampil.

f) Komunikasi nondiskursif.

Untuk melakukan pengukuran hasil belajar ranah psikomotor, ada dua hal yang perlu di lakukukan oleh pendidik yaitu membuat soal dan membuat perangkat atau instrument untuk mengamati unjuk kerja peserta didik, soal untuk hasil belajar ranah psikomotor dapat berupa lembar kerja, lembar tugas. Instrumen untuk kerja peserta didik dapat berupa lembar observasi. 
Tes untuk mengukur ranah psikomotor adalah tes untuk mengukur penampilan kerja atau kinerja yang telah di kuasai oleh peserta didik. Tes tersebut dapat berupa, tes simulasi, dan tes unjuk kerja.

a) Tes simulasi

Kegiatan psikomotorik yang di lakukan melalui tes ini, jika tidak ada alat yang sesungguhnya dan yang dapat dipakai untuk memperagakan penampilan peserta didik, sehingga peserta didik dapat di nilai tentang penguasaan keterampilan dengan bantuan peralatan tiruan atau berperaga seolah-olah menggunakan suatu alat yang sebenarnya.Tes unjuk kerja (Work Sample)

Kegiatan psikomotor yang di lakukan melalui tes ini, dilakukan dengan sesungguhnya dan tujuannya untuk mengetahui apakah peserta didik sudah menguasai.

Tes simulasi dan tes unjuk kerja, semuanya dapat diperoleh dengan observasi langsung ketika peserta didik melakukan pembelajaran. Lembar observasi dapat menggunakan daftar cek (check-list) atau skala penilaian (ranting scale). Psikomotorik yang di ukur dengan menggunakan alat ukur berupa skala penilaian tentang dari sangat baik, baik, kurang, dan tidak baik

\section{Deskripsi Data}

1) Data Kualitas Metode Praktek

Data kualitas Metode praktek diperoleh melalui penilaian para ahli, yaitu Prapti Karomah, M.Pd selaku ahli Metode dari program studi Pendidikan Teknik KKBT dan Rara Rilla, S.Pd selaku guru mata pelajaran tekstil. Aspek penelitian terdiri dari 4 parameter, yaitu tampilan praktek, penggunaan bahasa, tata letak dan bentuk penomoran, serta organisasi, yang kemudian dijabarkan dalam 23 pertanyaan. Hasil penilaian masing-masing ahli Metode dapat dilihat pada Tabel 1.

\begin{tabular}{l|c|c|c}
\multirow{2}{*}{\begin{tabular}{c} 
Ahli $\begin{array}{c}\text { Metode dan Guru } \\
\text { Mapel Tekstil }\end{array}$ \\
\cline { 2 - 4 }
\end{tabular}} & Point Total & Rerata & Persentase Kelayakan \\
\hline (1)Prapti Karomah, M. Pd & 120 & 4,61 & $92 \%$ \\
\cline { 3 - 4 } & & (Sangat Layak) & (Sangat Layak) \\
\hline (2) Rara Rilla W, S. Pd & 104 & 4,00 & $80 \%$ \\
\cline { 3 - 4 } & & (Layak) & (Layak)
\end{tabular}


Setelah penilaian yang berupa angket digabungkan, maka diperoleh data berikut

\begin{tabular}{l|l|l|l|l|l|l|c|c|c|c}
\multirow{2}{*}{ No } & \multicolumn{1}{|c|}{ Aspek Kualitas } & 1 & 2 & 3 & 4 & 5 & Score & Futir & $\begin{array}{c}\text { Rata- } \\
\text { rata }\end{array}$ & $\%$ \\
\cline { 3 - 12 } & Tampilan praktek & - & - & - & 16 & 6 & 47 & 11 & 4,27 & 85 \\
\hline 2 & Penggunaan bahasa & - & - & - & 9 & 5 & 30,5 & 7 & 4,35 & 87 \\
\hline 3 & $\begin{array}{l}\text { Tata letak dan bentuk } \\
\text { penomoran }\end{array}$ & - & - & - & 6 & 4 & 22 & 5 & 4,4 & 88 \\
\hline 4 & Organisasi & - & - & - & 5 & 1 & 12,5 & 3 & 4,15 & 83 \\
\hline $\begin{array}{l}\text { Jumlah } \\
\text { Tabel 2.Sebaran Uji dari Aspek Kualitas Menurut Ahli Metode }\end{array}$
\end{tabular}

2) Materi Praktek

Data kualitas Metode praktek diperoleh melalui penilaian para ahli, yaitu Noor Fitrihana, M.Eng selaku ahli materi bidang tekstil dari program studi Pendidikan Teknik KKBT dan Rara Rilla, S.Pd selaku guru mata pelajaran tekstil. Dimana aspek penilaian terdiri dari 25 butir dengan indikatornya yaitu, relevansi dengan silabus, relevansi dengan tujuan pembelajaran, penyampaian materi, pemilihan materi, kejelasan materi, keruntutan materi, serta mempermudah pemahaman siswa.

Masing-masing lembar penilaian yang telah diisi kedua validator kemudian digabungkan, dan diperoleh data sesuai Tabel 3.

\begin{tabular}{|c|c|c|c|c|c|c|c|c|c|c|}
\hline \multirow{2}{*}{ No } & \multirow{2}{*}{ Aspek Kualitas } & \multicolumn{5}{|c|}{ Frekuensi } & \multirow{2}{*}{$\begin{array}{c}\sum \\
\text { Score* }\end{array}$} & \multirow{2}{*}{$\begin{array}{c}\sum \\
\text { Butir }\end{array}$} & \multirow{2}{*}{$\begin{array}{l}\text { Rata- } \\
\text { rata }\end{array}$} & \multirow{2}{*}{$\%$} \\
\hline & & 1 & 2 & 3 & 4 & 5 & & & & \\
\hline 1 & Relevansi dengan silabus & - & - & - & 2 & 2 & 18 & 2 & 4,50 & 90 \\
\hline 2 & $\begin{array}{l}\text { Relevansi dengan } \\
\text { tujuan pembelajaran }\end{array}$ & - & - & - & 4 & - & 16 & 2 & 4,00 & 80 \\
\hline 3 & Penyampaian materi & - & - & - & 4 & - & 16 & 2 & 4,00 & 80 \\
\hline 4 & Pemilihan materi & - & - & - & 10 & 2 & 50 & 6 & 4,16 & 83 \\
\hline 5 & Kejelasan materi & - & - & - & 12 & - & 48 & 6 & 4,00 & 80 \\
\hline 6 & Keruntutan materi & - & - & - & 6 & - & 24 & 3 & 4,00 & 80 \\
\hline 7 & $\begin{array}{l}\text { Mempermudah } \\
\text { pemahaman siswa }\end{array}$ & - & - & - & 8 & - & 32 & 4 & 4,00 & 80 \\
\hline Jum & & & & & 46 & 4 & 204 & 25 & 4,09 & 81,85 \\
\hline
\end{tabular}

Tabel 3. Sebaran Uji Dari Aspek Kualitas Menurut Ahli Metode

3) Data Hasil Pretest 
Pretest diberikan untuk mengetahui sejauh mana pengetahuan siswa tentang materi pembuatan kain tenun sebelum peserta didik diberikan materi tersebut. Data pencapaian kompetensi belajar peserta didik sebelum perlakuan dibagi menjadi dua kelompok, yaitu kelas eksperimen dan kelas kontrol, dimana kelas eksperimen memperoleh perlakuan khusus berupa pemberian Metode berupa praktek pembelajaran pengetahuan pembuatan kain tenun, sedangkan kelas kontrol tanpa perlakuan khusus.

4) Data Hasil Posttest

Data hasil posttest peserta didik dibagi menjadi dua, yaitu kelas eksperimen dan kelas kontrol.

a. Data Hasil Posttest Kelas Eksperimen

Berikut data hasil pretest kelas eksperimen, yaitu kelas X KKBT 3 SMKN 1 Gunung Jati Cirebon dengan contoh siswa 10.

\begin{tabular}{c|c|c} 
No. Absen & Nilai & Keterangan \\
\hline 1 & 86 & Lulus \\
\hline 2 & 88 & Lulus \\
\hline 3 & 84 & Lulus \\
\hline 4 & 66 & Tidak Lulus \\
\hline 5 & 98 & Lulus \\
\hline 6 & 94 & Lulus \\
\hline 7 & 88 & Lulus \\
\hline 8 & 64 & Tidak Lulus \\
\hline 9 & 98 & Lulus \\
\hline 10 & 92 & Lulus
\end{tabular}

Berdasarkan data Tabel diatas didapatkan rata-rata nilai peserta didik (mean) adalah 80,18, Metoden sebesar 84, modus 66, nilai minimum yaitu 50, serta nilai maksimum sebesar 98. Adapun tingkat kelulusan peserta didik sebanyak $63,63 \%$.

Diagram dari distribusi frekuensi skor nilai pretest kelas eksperimen dapat dilihat pada gambar berikut. 


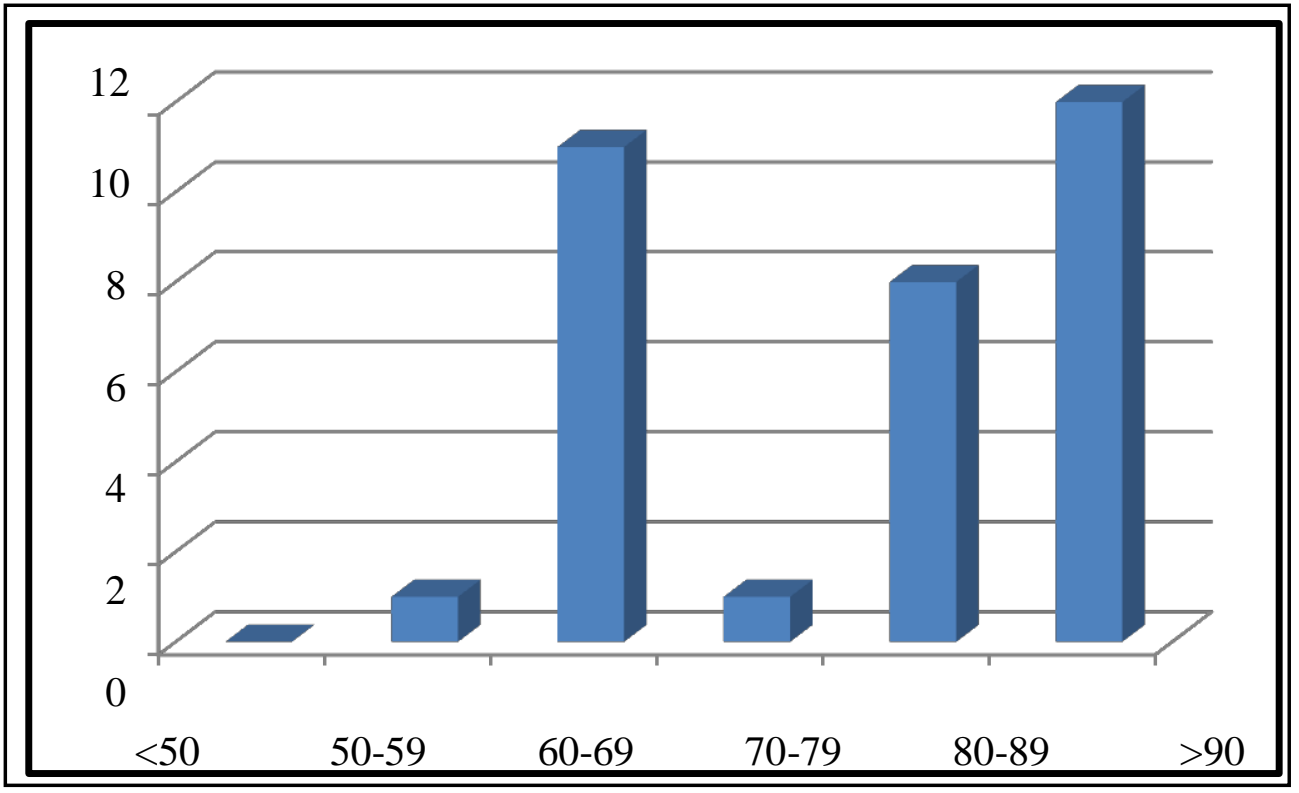

Berdasarkan Gambar 9 dapat diketahui bahwa skor nilai postest kelas eksperimen paling banyak pada interval di atas 90 dengan persentase sebesar $36 \%$, sedangkan jumlah siswa dengan nilai di atas 70 (lulus) sebanyak 63,63\% (skor minimum 10 dan skor maksimum 100), dengan skor rata-rata yaitu 80,18.

b. Data Hasil Posttest Kelas Kontrol

\begin{tabular}{c|c|c} 
No. Absen & Nilai & Keterangan \\
\hline 1 & 88 & Lulus \\
\hline 2 & 52 & Lulus \\
\hline 3 & 76 & Lulus \\
\hline 4 & 52 & Tidak Lulus \\
\hline 5 & 84 & Lulus \\
\hline 6 & 62 & Tidak Lulus \\
\hline 7 & 80 & Lulus \\
\hline 8 & 74 & Lulus \\
\hline 9 & 86 & Lulus \\
\hline 10 & 58 &
\end{tabular}

Berikut adalah data hasil pretest kelas kontrol, yaitu kelas X KKBT 2 SMKN 1 Gunung Jati Cirebon dengan contoh siswa 10.

Berdasarkan Tabel 19 didapatkan rata-rata nilai peserta didik (mean) adalah 72,41 , Metoden sebesar 70, modus 80 , nilai minimum yaitu 48 , serta nilai maksimum sebesar 96. Adapun tingkat kelulusan peserta didik sebanyak 55,88\%.

Berdasarkan Gambar 10 dapat diketahui bahwa skor nilai postest kelas kontrol paling banyak pada interval 60-69 dengan persentase sebesar $26,47 \%$, sedangkan 
jumlah siswa dengan nilai di atas 70 (lulus) sebanyak 55,88\% (skor minimum 10 dan skor maksimum 100), dengan skor rata-rata yaitu 72,41.

\section{5) Pengujian Persyaratan Analisis}

Sebelum uji hipotesis dilakukan, maka persyaratan analisis untuk uji hipotesis yang berupa uji normalitas dan uji homogenitas harus terpenuhi.

1. Uji Normalitas

Uji normalitas dimaksudkan untuk menguji apakah sebaran data variabel berdistribusi normal atau tidak. Uji yang digunakan adalah uji KolmogorovSmirnov. Penghitungan dilakukan dengan bantuan program SPSS.

\begin{tabular}{l|l|l|l|l} 
No & Perlakuan & $\mathrm{p}$-value & $\alpha$ & Keterangan \\
\hline 1 & Pretest & 0,553 & 0,05 & Normal \\
\hline 2 & Posttest & 0,589 & 0,05 & Normal \\
Rangkuman Uji Normalitas Kelas Kontrol & &
\end{tabular}

\begin{tabular}{l|l|l|l|l} 
No & Perlakuan & p-value & $\alpha$ & Keterangan \\
\hline 1 & Pretest & 0,557 & 0,05 & Normal \\
\hline 2 & Posttest & 1,194 & 0,05 & Normal \\
Rangkuman Uji Normalitas Kelas Eksperimen & &
\end{tabular}

2. Uji Homogenitas

Uji homogenitas dimaksudkan untuk mengetahui apakah sebaran data homogen atau tidak. Analisa yang digunakan adalah one-way anova, dengan aplikasi spss. Hasil uji homogenitas data dapat dilihat pada Tabel 19.

\begin{tabular}{l|l|l|l|l} 
No & Perlakuan & $\mathrm{p}$-value & $\alpha$ & Keterangan \\
\hline 1 & Pretest & 0,438 & 0,05 & Homogen \\
\hline 2 & Posttest \\
Rangkuman Uji Homogenitas
\end{tabular}

\section{6) Pengujian Hipotesis}

1. Uji Hipotesis

Uji hipotesis dilakukan untuk mengetahui apakah hipotesis awal penelitian diterima atau ditolak. Uji hipotesis ini diolah dengan menggunakan t-test. T-test atau uji t dibagi menjadi 3 yaitu uji t pretest dan posttest kelas kontrol, uji t pretest dan posttest kelas eksperimen, serta uji $\mathrm{t}$ posttest kelas kontrol dengan kelas eksperimen. Kesimpulan penelitian dinyatakan signifikan apabila $\mathrm{t}$ hitung $>\mathrm{t}$ tabel pada taraf 5\% dan nilai $\mathrm{p}<0,05$. Tabel distribusi $\mathrm{t}$ dicari pada $=5 \%: 2=2,5 \%$ (uji 2 sisi) dengan derajat kebebasan (df) n-1.

a. Uji t pretest dan posttest kelas kontrol

Tujuan uji t pretest dan posttest kelas kontrol yaitu untuk mengetahui ada tidaknya peningkatan skor nilai. Berikut hasil analisis uji t kelas kontrol.

$$
\text { Kelas } \quad \mid \text { Rata-rata } \mid \mathrm{t} \text { hitung } \mid \mathrm{t} \text { tabel } \mid \mathrm{p}
$$




\begin{tabular}{c|l|l|l|l} 
Pretest kelas kontrol & 38,41 & & \\
\hline Posttest kelas kontrol & 72,41 & 10,107 & 2,034 & 0,00
\end{tabular}

Tabel 2.Hasil Analisis Uji t Kelas Kontrol

b. Uji t pretest dan posttest kelas eksperimen

Tujuan uji t pretest dan posttest kelas eksperimen yaitu untuk mengetahui ada tidaknya peningkatan skor nilai. Berikut hasil analisis uji t kelas eksperimen.

\begin{tabular}{c|c|c|c|c} 
Kelas & Rata-rata & $\mathrm{t}$ hitung & $\mathrm{t}$ tabel & $\mathrm{p}$ \\
\hline Pretest kelas eksperimen & 36,85 & & & \\
\cline { 1 - 2 } $\begin{array}{c}\text { Posttest kelas eksperimen } \\
\text { Tabel 3. Hasil Analisis Uji t Kelas Eksperimen }\end{array}$ & $\begin{array}{l}80,18 \\
\text { Ekn }\end{array}$ & 2,036 & 0,00 \\
\end{tabular}

c. Uji t posttest kelas kontrol dan posttest kelas eksperimen

Tujuan uji $\mathrm{t}$ posttest kelas kontrol dan posttest kelas eksperimen yaitu untuk mengetahui ada tidaknya peningkatan skor nilai. Berikut hasil analisis uji t kelas kontrol dan eksperimen.

\begin{tabular}{c|c|c|c|c} 
Kelas & Rata-rata & $\mathrm{t}$ hitung & $\mathrm{t}$ tabel & $\mathrm{p}$ \\
\hline Posttest kelas kontrol & 72,41 & & & \\
\cline { 1 - 2 } Posttest kelas eksperimen & 80,18 & 2,324 & 2,036 & 0,00
\end{tabular}

Tabel 4. Hasil Analisis Uji T Kelas Kontrol dan Kelas Eksperimen

\section{B. Pembahasan}

1. Pembelajaran dan Hasil Belajar Siswa Pada Kompetensi Pengetahuan Pembuatan Kain Tenun Kelas Kontrol

Pendekatan yang digunakan dalam proses pembelajaran kelas kontrol yaitu saintifik. pendekatan pembelajaran ini adalah salah satu cara mengimplementasikan Kurikulum 2013 Revisi, dimana penekanan pembelajaran yaitu pada keaktifan siswa. ada lima kegiatan utama dalam proses pembelajaran menggunakan pendekatan saintifik, yaitu mengamati, menanya, mengumpulkan informasi, mengasosiasi, dan mengomunikasikan. Adapun metode yang digunakan yaitu metode ceramah, atau penyampaian bahan pelajaran dengan komunikasi lisan. Alat bantu atau Metode yang dipakai seperti papan tulis dan LCD.

Proses pembelajaran kelas kontrol, siswa cenderung kurang aktif baik dalam mengajukan pertanyaan maupun mengomunikasikan permasalahan yang diajukan oleh guru. Metode video yang ditampilakan cukup menarik perhatian siswa, namun ketika guru memberikan pertanyaan yang berkaitan dengan isi video siswa masih pasif. Sedangkan kunjungan industri yang dilakukan di tengah pemberian materi cukup memberikan pengetahuan pada siswa, namun tidak semaksimal siswa kelas eksperimen yang dibekali praktek pengetahuan pembuatan kain tenun.

Berdasarkan hasil uji t berpasangan, nilai rata-rata pretest kelas kontrol adalah 38,41, sedangkan nilai posttest meningkat menjadi 72,41. Adapun signifikansi peningkatan nilai kelas kontrol, diketahui nilai t hitung lebih besar dari nilai tabel $(10,107>2,034)$ dengan nilai signifikansi kurang dari 0,05 yaitu 0,00. Jadi, dapat dinyatakan ada peningkatan hasil belajar siswa pada kelas kontrol. 
2. Pembelajaran dan Hasil Belajar Siswa Kompetensi Pengetahuan Pembuatan Kain Tenun Kelas Eksperimen

Sama halnya dengan pendekatan pembelajaran yang digunakan di kelas kontrol, pembelajaran di kelas eksperimenpun menggunanakan pendekatan saintifik yang menekankan pada keaktifan siswa, yaitu mengamati, menanya, mengumpulkan informasi, mengasosiasi, dan mengomunikasikan. Metode yang digunakan berupa metode ceramah. Adapun treatment atau perlakuan yang diterapkan di kelas eksperimen berupa penerapan praktek pembelajaran pengetahuan pembuatan kain tenun. Adapun keaktifan siswa di kelas eksperimen dapat dikatakan tinggi, karena hampir seluruh siswa antusias dan mampu menjawab ketika ada pertanyaan yang dilontarkan oleh guru.

Kunjungan industri yang dilakukan di tengah materi (di luar jam pelajaran) sangat terbantu dengan adanya praktek yang diberikan ke siswa. Setiap siswa dapat mengamati proses penenunan di industri dan membandingkan dengan teori-teori dalam praktek, sehingga daya ingat dan pemahaman siswa lebih baik. Begitupun pada saat guru menayangkan video tentang penenunan, antusias siswa samakin meningkat.

Berdasarkan hasil uji t berpasangan, nilai rata-rata pretest kelas eksperimen adalah 36,85, sedangkan nilai posttest meningkat menjadi 80,18. Adapun signifikansi peningkatan nilai kelas kontrol, diketahui nilai t hitung lebih besar dari nilai tabel $(14,044>2,034)$ dengan nilai signifikansi kurang dari 0,05 yaitu 0,00 . Jadi, dapat dinyatakan ada peningkatan hasil belajar siswa pada kelas eksperimen setelah penerapan praktek pembelajaran pengetahuan pembuatan kain tenun.

3. Perbedaan Hasil Belajar Siswa Pengetahuan Pembuatan Kain Tenun Antara Kelas Kontrol Dengan Kelas Eksperimen

Perbedaan hasil belajar atau kompetensi siswa yang menerapkan Metode praktek pembelajaran dengan siswa yang menggunakan metode konvensional (ceramah berbantuan papan tulis) cukup signifikan. Hal ini dapat dilihat dari kenaikan dan rata-rata nilai posttest yang diperoleh kedua kelas, yaitu kelas kontrol dengan kenaikan sebanyak 34,00 dan rata-rata 72,41 pada posttest, sedangkan kelas eksperimen mengalami kenaikan yang lebih besar yaitu sebanyak 43,33 dengan rata-rata 80,18 pada posttest.

Pelaksanaan pembelajaran antara kelas kontrol dengan kelas eksperimen banyak terdapat perbedaan, diantaranya yaitu tingkat keaktifan dan partisipasi siswa, dimana pada kelas eksperimen siswa sangat aktif dan antusias, sebaliknya pada kelas kontrol siswa cenderung masih pasif. Adapun bagi pengajar, menerapkan Metode praktek dirasa sangat membantu, terutama untuk membandingkan antara gambar komponen dengan namanya, serta teori pembuatan kain tenun. Guru tidak harus menjelaskan secara lengkap semua materi, cukup menuliskan point-point penting pada papan tulis, kemudian siswa diminta memahami isi praktek sendiri. Sedangkan untuk kelas kontrol, pengajar harus benar-benar menerangkan dan menuliskan materi di papan tulis. Dengan jumlah siswa sebanyak 34 orang hal ini terbilang sulit.

Jadi, penggunaan praktek pembelajaran pembuatan kain tenun lebih efektif, karena menuntut kemandirian siswa sedang guru hanya sebagai vasilitator, sehingga lebih dapat meningkatkan minat dan ingatan siswa. 


\section{Bibliografi}

Kemmis, S., \& Taggart, M. (2002). R. 1988. The Action Research Planner.

Munadi, Y. (2013). Media Pembelajaran Sebuah Pendekatan Baru. Jakarta: Cet. I. GP Press Group.

Suharsimi, A. (2006). Prosedur penelitian suatu pendekatan praktik. Jakarta: Rineka Cipta.

Allen, M.J. \& Yen, W.M. (1976). Introduction to Measurement Theory. California : Brook/Cole Publisher

Arikunto, S. (2012). Prosedur Penelitian Suatu Pendekatan Praktek. Jakarta: Rikena Cipta.

Creswell, John W. (2004). Research in Education. New York: SAGE

Djamarah. (2012). Prestasi Belajar dan Kompetensi Guru. Surabaya: Usaha Nasional.

Fitrihana, Noor. (2010). Teknologi Tekstil dan Fashion. Yogyakarta: Fakultas Teknik UNY

Hamalik, Oemar. (2011). Proses Belajar Mengajar. Jakarta: PT Bumi Aksara

Kusaeri \& Suprananto. (2012). Pengukuran dan Penilaian Pendidikan. Yogyakarta: Graha Ilmu

Martoyo, Susilo. (2007). Manajemen Sumber Daya Manusia. Yogyakarta: BPFE Yogyakarta

Miller, M.D., Linn, R.L., \& Gronlund, N.E. (2009). Measurement and Assessment in Teaching. Upper Saddle River, N.J. : Pearson

Mulyasa. (2010). Kurikulum Berbasis Kompetensi. Bandung: Remaja Rosdakarya

Munadi, Yudhi. (2013). Metode Pembelajaran Sebuah Pendekatan Baru. Jakarta:

Referensi

Muslich, Masnur.(2011). KTSP Kurikulum Tingkat Satuan pendidikan. Jakarta: PT Bumi Aksara

Nitko, Anthony J. 2011. Educational Assessment of Students.Englewood Cliffs. NJ: Prentice-Hall, Inc

Sanjaya, Wina. (2009). Strategi Pembelajaran Berorientasi Standar Pendidikan. Jakarta: Kencana

Siagaan, Sondang P. (2006). Manajemen Sumber Daya Manusia. Jakarta: Bumi Aksara

Smaldino, Sharon. (2011). Instructional Technology and Metode for Learning: Teknologi Pembelajaran dan Metode untuk Belajar. (Alih Bahasa: Arif Rahman). Jakarta: Kencana

Sudjana, Nana. (2012). Metode penelitian pendidikan. Bandung: Falah Production Sugihartono dkk. (2007). Psikologi Pendidikan. Yogyakarta: UNY Press

Sugiyono. (2010). Statistika untuk Penelitian. Bandung: Alfabeta Syamsi, Ibnu. (2000). Pengambilan Keputusan Sistem Informasi. Jakarta: Bumi Aksara

Syaodih, Nana. (2013). Metode Penelitian Pendidikan. Bandung: Remaja Rosdakary Uno, Hamzah. (2012). Perencanaan Pembelajaran. Jakarta: PT Bumi Aksara 